\title{
Cultural Animation - Philosophical Grounding and Practical Use ${ }^{1}$
}

\author{
Anna Dudová, Michal Kaplánek, Richard Macků
}

When the Council of Europe in 1978 recommended that its member states develop animation, it definitely meant sociocultural or social animation. ${ }^{2}$ Sociocultural animation is a method of social work realized mostly within the framework of community work. It is based on trust in the cultural potential concealed in the underprivileged part of the population, which without such animation would often have no chance to discover, develop and assert its potential. ${ }^{3}$ At first glance it is a radically democratic, leftist approach. Such understanding of animation is at first glance in direct contradiction to the idea of traditional education, which has for centuries been grounded in the principle of transmitting values, attitudes and thought patterns from generation to generation, where what "is to be transmitted" is determined by an authority (up to the time of Enlightenment it was the Church, or churches, later the state). ${ }^{4}$ If we are to look for educational elements in sociocultural animation, it would rather be "empowerment" in the sense of promoting the emancipative tendencies of the people and their ability to participate in the political and social development of their environment.

Animation thus conceived went through a boom in the 1970s. Against this backdrop we can easily understand that the "educational use" of animation, as it was proposed at the beginning of the 1970s by the young Italian psychologist Mario Pollo, seemed to many social activists of the time like "misusing a progressive idea to reactional goals". The discussion among the Italian and French theorists of animation of the time resembles in some points the contemporary Czech discussion in social work. It concerns a similar dilemma: To what extent should a social worker, educator or another representative of the majority society influence the actions of those who are on its margins, and to what extent must she respect their freedom, even when these people are harming themselves and others? ${ }^{5}$ The educational public got to know Pollo's conception of animation through texts by Juan Edmond Vecchi, originally written in Spanish. ${ }^{6}$ Pollo's conception of animation is based on anthropological grounds formulated in the works of outstanding Jewish and Christian philosophers and psychologists of the 20th century. These are followed by a theological interpretation of the contemporary human situation developed by theologians who had adopted Pollo's conception (Prieto, Tonelli, Vallabaraj). The key moment in the animation conception of education is the person of the educator - animator. In her educational attitudes and actions animation can be recognized; it can be realized only by preparing animators. That is why the key part of this paper is devoted to the animator's profile and the concluding part to the preparation of animators in Salesian context. How the idea of animation is

\footnotetext{
1 This paper was written as part of the project of specific research GAJU 117/2013/H - Conception of the quality of social work in the context of the social worker's self-definition and her assisting profession.

2 It is one of the most widespread lines of animation deriving from the idea of social culture, designated as sociocultural or social animation. The Council of Europe recommendation is called Sociocultural Animation (Strassbourg: Council of Europe - Council for Cultural Cooperation, 1978).

3 On this topic see Michal KAPLÁNEK, Sociálně kulturní práce v lidových vrstvách, Caritas et veritas 2/2011, pp. 30-37.

4 The lack of "partner attitude" in education, as well as using and abusing authority on the part of the elites was criticized by Paulo Freire, Hannah Arendt and many others.

5 Dilemmas formulated by Matisson (Social Work, 2000) are presented e.g. by Aleš Herzog (cf. Aleš HERZOG, Nízkoprahovost a její nároky na pracovníky, in: Teologie a sociální práce - dvacet let dialogu, ed. Michal KAPLÁNEK, Praha: Jabok, 2013, pp. 113-119).

6 Cf. Jan PRƯCHA - Eliška WALTEROVÁ - Jiří MAREŠ, Pedagogický slovník, Praha: Portál, 1995, p. 21.
} 
reflected in Czech and Slovak pedagogical literature is briefly analysed in our paper The Pluriform Phenomenon of Animation. ${ }^{7}$

\section{Animation in education}

The 1960s, which culminated in student and worker unrest in Western Europe, the Woodstock festival in North America and the Prague Spring in Czechoslovakia, were characterised by the youth's loss of trust in the institutions headed by the generation of their parents; this crisis affected both the family and the church, the school and the state. People working in education, like e.g. the Salesian Riccardo Tonelli, perceived the need to start addressing young people in quite different manner than used to be customary - the school and the family were losing influence and young people were losing interest in traditional associations. The youth was gathering itself, spontaneously - it was forming peer-groups living in a way quite different from the adults. We speak of the rise of subcultures. When studying in France Mario Pollo got to know animation as a means by which adults could reach these groups. However, he did not like the leftist form of sociocultural animation, which provided no guidance for the young, merely encouraged them to fight "for their rights" ${ }^{8}$ His view of education derived from the Judeo-Christian tradition. The term "cultural animation" used by Pollo to designate his philosophical and pedagogical conception assumes that the goal of education is enculturation, i.e., becoming part of the cultural tradition of the society we live in, whose values we (more or less) accept. The foundation of cultural animation is anthropology based on the ideas of mostly Jewish philosophers of the 20th century (Cassirer, Wittgenstein, Arendt, Fraser and others). These ideas are set in the context of the Christian doctrine on grace. ${ }^{9}$ Pollo perceives the human being as a being with a transcendental determination. That is why in his conception an animator must be spiritually ripe, able to approach the great mystery of the human being and willing to help children and the young to form a life vision (progetto della vita).

Pollo views the human being in seven ways: ${ }^{10}$

1) as a mystery;

2) as a being who plans, creates culture and expresses herself by means of symbols;

$3)$ as a being with psychological experience;

4) as a being living in time and heading towards death;

5 ) as a being who has values and needs;

6) as a free creature;

7) as a being who is finite and at the same time longs for infinity.

He thus sees the human being as a (paradoxical) mystery, in which being temporally as well as potentially limited (finitude) is conjoined with a longing for crossing these limits (transcendence) and with freedom which manifests itself in the priority of (moral) values and symbolic expressions of culture. ${ }^{11}$

7 Cf. Anna DUDOVÁ - Michal KAPLÁNEK - Richard MACKU゚, Mnohotvarý fenomén animace, Pedagogická orientace 3/2011, 295-300.

8 Mario Pollo's critical comments on sociocultural animation are found in his books (e.g. Animazione culturale), for the biographical context of his life we draw on the interview with him conducted by M. Kaplánek in March 2010.

9 "A further key value of animation is gratuità (i.e., the fact that we receive the essential gifts free of charge, which is the foundation of the Christian idea of grace, Lat. gratia - M. Kaplánek's note)... Gratuità, celebration and game are accompanying values, which follow after the gift of the (Christ's) cross, the steep path of redeeming human beings in the exile where they still live." (Mario POLLO, Animazione culturale, Roma: LAS, 2004, p. 26.)

10 For more detailed discussion of the topic see Michal KAPLÁNEK, Animace, Praha: Portál, 2013 , pp. 51-60.

11 Pollo's conception of cultural animation is described in detail in Mario POLLO, Animazione culturale. 
When we critically examine the above seven characteristics of human beings, which constitute the philosophical foundation of cultural animation, we find that no specific religious faith is necessary to realize them. It is rather a matter of respecting the mystery of the human being, her life, death, as well as hope for eternity; respecting the human being as a religious being, but at the same time a weak and sinful being who lives in the discord of contemporary world and needs redemption. Cultural animation can thus be employed by persons who are not members of any religious society. The presupposition of this animational approach is respect for the human being as a mystery and endorsing the traditional values of European culture, historically formed by the Judeo-Christian tradition, which in contemporary political discourse is customarily called "conservative".

\section{Theological context of cultural animation}

We have just stated that although cultural animation is not a method "reserved" to the members of some church, it is nonetheless quite clearly and transparently derived from the JudeoChristian tradition and developed in Catholic context. It is therefore appropriate to ask whether there exists something like a theology of cultural animation and what its basic features are. To find an at least somewhat satisfactory answer to the question we must not limit ourselves to the ideas of its founder Mario Pollo. We must also examine the work of Salesians who have developed this method further. These are especially the pastoral theologian Riccardo Tonelli from Italy, Jerome Vallabaraj from India, extraordinary professor at the Papal Salesian University in Rome, and the Mexican Salesian Javier Prieto. Together with Mario Pollo Tonelli co-created the contemporary profile of cultural animation and advocated it as a method suitable for youth ministry. Vallabaraj used cultural animation as the foundation for his conception of holistic education and Prieto created a useful aid for animator preparation, available also in Slovak. ${ }^{12}$ In the works of these authors we can find the following theological accents, which do not suggest any integrated system of theological reflection within the framework of cultural animation, but have definitely affected the development of the animational approach in education:

1) Incarnation as the theological foundation of the human being's relationship to the world and herself

In his memories from 2009 Tonelli recalls this choice with the following words: "We discovered ... the pastoral dimension of the event of the Incarnation ... In Jesus from Nazareth it was possible to discover God in his authenticity, to meet him as the total meaning of our life in the weakness and grace of his humanity. In him we found ... our own humanity, our life." This "discovery" had practical pastoral consequences, namely appreciating the "theological meaning of everyday life, this great sacrament of God's presence and encountering God in Jesus". ${ }^{13}$

2) The human being needs salvation (liberation)

Life is a sacrament when it is authentic and corresponds to God's purpose. But real life is "contaminated with sin". That is why Tonelli views education as a "privileged instrument by means of which we can return her life quality to every person". In other words: "we need salvation" and "education is a means of salva-

12 Riccardo TONELLI, Pastorale giovanile e animazione, Torino: Elledici, 1970; Jerome VALLABARAJ, Animating the Young. An Introduction to a Holistic Paradigm of Youth Ministry, Bangalore: Kristu Jyoti Publications, 2005; Javier PRIETO, Smer - človek. Kurz pre animatorov, Bratislava: Don Bosco, 1996.

13 Riccardo TONELLI, Ripensando quarant'anni di servizio alla pastorale giovanile. Intervista a cura di Giancarlo De Nicolò, p. 18, Note di Pastorale giovanile 5/2009, pp. 11-65. 
tion" ${ }^{14}$ The need for salvation is the basis of animation also in the conception of Pollo, who is aware of human finitude and limits.

3) The priority of the process of salvation to salvation mediation

Like Rahner, Tonelli distinguishes between the process of salvation and salvation mediation. The process of salvation is the realization and personal acceptance of salvation. On the other hand, the mediation of salvation depends on the historical nature of the Church (as an institution). The process of salvation is a personal free act of each human being. This personal decision comes through one's own free communication with God in (the context of) his grace. This is not subject to Church governance. However, it is the Church's task to support the process of salvation, to create opportunities and conditions for it. ${ }^{15}$ Rahner's key idea is: "Faith and justification exist before they are mediated by the Church, even before the Gospel is preached."16

4) Animation nurtures the process of transforming one's life as answer to God's call According to Vallabaraj, ${ }^{17}$ animation means accompanying by counsel and motivation. Such accompanying aims to assist the young in forming their life vision, which can only be realized in authentic and free relationships in which individuals are encouraged to recognize their mission in life. It is thus a human answer to God's vocation. If we want to see animation as an enrichment of life, then we construe it as a process and method which accepts the constant changeability of life; for a Christian faithful it is God who through Jesus Christ is the source of growth and development of the human person. If we understand animation as a movement transforming life, then animation becomes a strategy, the central element of which is life and love for life. The goal of this transformation is the fullness of life, which is revealed for all by Christ and in Christ. ${ }^{18}$ According to Vallabaraj the theological foundation of animation is the conviction that "in Jesus Christ God calls us to radical love". ${ }^{19}$

\section{The profile of an animator}

In all conceptions of animation the animator is the key figure. In the conception of cultural animation the animator is a person who preserves her identity and at the same time offers high quality pedagogical accompanying.

The animator is the group's fellow traveller. She orients, stimulates and accompanies it, harmonizes the differences between the individual members, arouses hope and trust. She must be a trustworthy person whom everybody likes to approach. She is to be a model because she herself is undergoing maturation. That is why she can witness to the traditional values which are part of her identity. ${ }^{20}$

\footnotetext{
14 Ibid., pp. 18 and 20.

15 Cf. Riccardo TONELLI, Pastorale giovanile. Dire la fede in Gesù Cristo nella vita quotidiana. 4. ed. riveduta e aggiornata, Roma: Libreria Ateneo Salesiano, 1987, p. 18.

16 Karl RAHNER (et al.), La salvezza nella Chiesa. Strutture fondamentali della mediazione salvifica, Brescia, 1968, p. 14.

17 Our source is the Italian version of Vallabaraj's work Animating the Young, Jerome VALLABARAJ, Animazione e pastorale giovanile.

Un'introduzione al paradigma olistico, Torino: Elledici, 2008.

18 Cf. Jerome VALLABARAJ, Animazione e pastorale giovanile, p. 17.

19 Ibid., p. 19

20 Cf. Javier PRIETO, Smer - človek, p. 208.
} 
Being an animator is neither an honorary function nor a career stage. Any sign of power approach or manipulation would mean misunderstanding the nature of animation. The animator must not impose her ideas on others, she can only offer them. ${ }^{21}$

Javier Prieto mentions six basic attitudes of an animator. The first one is trust in the human person. An animator trusts in every young person, especially in the good in them. Her task is to help people discover their own gifts (charismata), which are often unknown, hidden, unused, underestimated. The goal of an animator's activity is that her wards learn to trust their abilities, including the ability to face negative situations.

The second basic attitude is the liberating power of educatory love: In order for the young to develop the power of the good, they need to experience love which brings about liberation. By this attitude Prieto directly follows Don Bosco, the founder of Salesians (1815-1888). ${ }^{22}$ In Salesian education (and thus in J. Prieto's conception of animation) education is conceived as a path of evangelization.

An educator is to share a deep love for life with the young people. At the same time she helps them to discover what they can live for, to experience life as a gift, and thus to mature so that they can commit themselves to serve others in life.

A further element is protagonism in the educational process. The term "protagonism" is used in Italian to signify the ability to express oneself, to assert oneself and to lead others, to walk in the front row - in activity and in service. The animator strives to stimulate the desire of the young to grow as persons, respects their freedom and own steps. The goal is that the young learn to go their own way and assert themselves. The animator motivates and orients the energy of the young and shows them new possibilities and perspectives, accompanies them, helps them find and appreciate themselves. ${ }^{23}$

These attitudes should lead the animator to be able to actually decide to accept every young person such as she is, in order to create an educational environment that will become home, parish, school and playground for the participants. ${ }^{24}$ An animator is a person who has decided to be present among the young, to share their life and at the same time to witness. It is a peculiar exchange: The animator offers the young her inner wealth and at the same time learns from them. The animator also shares her attitudes with the young, by example and witness. ${ }^{25}$

For a Christian faithful animator the youth group is a space where she lives her experience with God. That is why her presence among the young is never wasted time for her.

\section{Practical realization of animation in Salesian context}

Although cultural animation originated among Italian Salesians, one would be mistaken to

21 Cf. ibid., p. 209.

22 Don Bosco in a letter from Rome (1884) encourages his pupils with the words: "It is not enough that you love them, the boys must feel that they are loved." (Giovanni BOSCO, List sv. Jána Boska z roku 1884. Nestačí ich milovat', Rím: SÚSCM, 1984, p. 36).

23 Cf. Javier PRIETO, Smer - človek, pp. 210-211.

24 Don Bosco formulated the mission of the oratory with four images, easily understandable in his times: home meant a family atmosphere and an environment of trust, parish was the place of socialization and development of spiritual life, school was the place where one could learn things useful for practical life, playground was a place of entertainment and spontaneous joy (Cf. Michal KAPLÁNEK, Výchova v salesiánském duchu, Praha: Portál, 2012, p. 20).

25 In Salesian context these attitudes are accompanied by religious ones. It thus becomes witness to faith. 
think that it has reached worldwide recognition as Salesian working method. It was created by Italians (Pollo and Tonelli), but it has become much more widespread among Salesians of the Spanish-speaking world. Tonelli himself suggests the following reasons why the conception has asserted itself so feebly:

- different approach of pastoral theologians and pedagogues at the Papal Salesian University;

- plurality of educational models;

- plurality of views of the human being. ${ }^{26}$

However, even the contemporary revised manual of Salesian youth ministry published by the Department for Youth Ministry of the Salesian Generalate House in Rome recommends educating in animational style. This style is further specified by the following characteristics:

- animation acknowledges the young persons' ability to assume responsibility;

- animation is a method that sees the positive qualities in each young person, her wealth and inner potential, and offers activities to develop it;

- animation is a style of accompanying young people by council, motivation and assistance in their everyday development by means of relationships based on freedom and own choice;

- the most important goal of animation is to return to every human being the joy of the fullness of life and the courage to hope. ${ }^{27}$

This brief characteristic of animation is followed by stating that animational style is grounded in the person of the animator, her attitudes and actions. The animator's tasks are to:

- support the development of youth groups in searching, reflection, activities and ideals;

- help overcome crises in the group and create relationships among the group members;

- bring elements of criticism and deeper reflection into the group, so that the young people learn to communicate their ideas, wishes and questions;

- support communication and cooperation among the individual groups in the local Salesian community;

- accompany individuals in their maturation as human beings and Christians. ${ }^{28}$

The current situation of animation as a method or approach in Salesian establishments can with some simplification - be summarized as follows: Salesians throughout the world have adopted some elements of cultural animation, especially the empirical-critical model of planning, working with groups and care of the overall maturity of animators. ${ }^{29}$

Attempts to introduce animation as an educational method which strives to bring a (young) person to discover for herself what to do in life and how, and what views to adopt, first appeared in the Czech context already in the 1990s through the journal NAIM - časopis pro pasto-

26 The information on Tonelli's observations and opinions comes from a personal interview with R. Tonelli conducted in April 2010 by M. Kaplánek.

27 Freely adapted from the book La Pastorale Giovanile Salesiana. Quadro di Riferimento, Roma: Direzione Generale Opere Don Bosco, 2014, p. 150.

28 Cf. La Pastorale Giovanile Salesiana, pp. 150-151.

29 On the individual elements of cultural animation see Michal KAPLÁNEK, Animace, pp. 61-96. 
raci mládeže. ${ }^{30}$ The person who initiated popularizing the animational approach was the Salesian Michael Martinek. He characterized animation in the context of youth ministry as an internal process of the young person's formation to maturity, stimulation by the educator based on a personal relationship. He understood animation as using educational methods and techniques sustaining the process. In his conception an animator is a person whose task is to activate the young people entrusted to her based on personal relationships, using animational methods and techniques in her work. She is not to be merely an organizer and manager, but rather to influence others primarily by her personal example and her relationship to each individual. ${ }^{31}$

Since the journal NAIM was only published 1994-1997 and was distributed only in the Catholic Church, the idea of cultural animation was developed only by a confined group. Salesians in the Czech Republic work according to the principles of cultural animation rather implicitly, in an actualization of the preventive system of Don Bosco. ${ }^{32}$ The preventive system can be characterized in a simplified manned by several distinctive elements, such as: being close to the young, being sensitive to them, accepting them unconditionally, dialogue, faith in the good in every human being, encouraging to own initiative. What is specific is the Salesian educational environment, where we find authentic human relationships, vitality and offer of personal growth. The environment is primarily formed by the young people themselves.

The Czech and Slovak Salesian environment has drawn on the same theoretical sources, following Italian, Spanish and Latin American authors. ${ }^{33}$ The brief information on animation found in Czech pedagogical literature, e.g. in the Pedagogical Dictionary of the author trio Průcha, Walterová, Mareš published in 1995, ${ }^{34}$ comes from the same sources.

Animation as an approach and method is better known in the Slovak Salesian context, where for the last twenty years Salesians have been trying to develop animation theoretically as well. The reason is the need to prepare Salesian volunteers - animators.

\section{The Slovak "School of Animation"}

In the last twenty years Slovak Salesians have established cultural animation in Slovak cultural and social context. From the very beginning they were aware that it is not just a matter of adopting the word animation, but rather of its "educational valorization" in the Salesian context. Slovak Salesians conducted extensive consultations with Javier Prieto, the already mentioned Mexican author of a manual for animator courses. Prieto came to Slovakia several times and helped to formulate the Slovak version of a animators' handbook. He also took part in the first animator courses.

One of the first course leaders and advocates of animation in Slovakia was Ladislav Baranyai. Baranyai was entrusted with the task of introducing animation into the Slovak Salesian context. Since 1994 young people in Slovak Salesian centres have been taking part in courses called School of Animation.

30 NAIM - časopis pro pastoraci mládeže, Praha: Salesiánská provincie Praha.

31 Cf. Michael MARTINEK, Animator skupiny, NAIM - časopis pro pastoraci mládeže 2/94, pp. 7-9; Michael MARTINEK, Animace, NAIM časopis pro pastoraci mládeže 1/94, pp. 11-13.

32 Cf. Michal KAPLÁNEK, Výchova v salesiánském duchu, Praha: Portál, 2012, pp. 86-88.

33 Juan E. VECCHI, Pastorale giovanile. Una sfida per la comunità ecclesiale, Torino: LDC, 1992; Riccardo TONELLI, Pastorale e animazione, Roma, 1990; Alfonso FRANCIA, Curso para jóvenes cristianos animadores de grupos. Dinámica de grupos, Madrid: Editorial CCS, 1989.

34 Cf. Jan PRŮCHA - Eliška WALTEROVÁ - Jiří MAREŠ, Pedagogický slovník, p. 21. 
The programme of these courses spans over three years and ends with a final exam. The manuals on the individual topics are divided into three parts: work, programme and study. In the work part there are questions and space for personal notes of the course participants. The programme part contains a detailed description of the whole course (for course leaders). In the study part there is information which further elaborates on the topic and inspires to further, more detailed study. ${ }^{35}$

These materials not only help animators in educating, they also stimulate their personal development. The topics help animators increase their competence and perfect their work with groups. Through them animators get to know the situation of contemporary youth in greater depth as well as the peculiarities of the environment they live in.

At present the formation of animators is realized as part of an extensive project Paths of Maturation. ${ }^{36}$ It is an educational project developed for individual age groups, homogenously divided (i.e., not co-educated). Only groups of the age 18-25 are mixed - there the problem of male-female relationships and their maturation is dealt with. The project counts with the peer-group and its dynamics. An important part is played by the animator who must meet special criteria. These correspond to Mario Pollo's requirements for an animator (personal maturity and ability to form authentic relationships). ${ }^{37}$

Animators from Salesian centres are sent to courses where they are introduced to the whole project and at the same time focus on the age group they work with. This is assisted by a carefully elaborated work material. ${ }^{38}$

\section{The possibility of applying the Slovak model in Czech context}

Czech and Slovak Salesian educational practice share an orientation on the free time of children and youth, but there are differences in the target groups Salesians work with. While the animators in Slovak Salesian centres are mostly young Christian faithful who form Christian communities, the situation in the Czech Republic is different. Here an important target group of Salesian work are socially underprivileged young people. ${ }^{39}$ The question is how to find animators meeting the high personality requirements formulated by the originators of the conception of cultural animation for such a target group. The question is who in fact meets such requirements.

An unconditional presupposition is human maturity. When we speak of the human maturity an educator ought to have, we mean precisely the ability to perceive human beings in their integrity, i.e., in the context of their physical, mental, social and spiritual life. At the same time an animator must be able to encourage people to form their own life vision, which will allow them to find a prospect in life (even if they in fact belong to an underprivileged group, e.g. the unemployed).

As with any profession, in the case of pedagogues it holds that a person must have disposi-

35 Cf. Ladislav BARANYAI, Príprava stretnutí a itinerárov, Bratislava: DOMKA, 2008.

36 Internet site of the project (online), available at http:/ / www.cestyzrenia.domka.sk

37 Cf. Michal KAPLÁNEK, Animace, pp. 38-39.

38 Cesty zrenia - dievčatá, Bratislava: DOMKA, 2010.

39 Cf. Michal KAPLÁNEK, Výchova v salesiánském duchu, pp. 63-67. 
tions for a particular activity. It does not mean that without inherited dispositions one cannot do such work, but she must work on her professional and personal development all the more. The abovementioned requirements for an animator, as formulated by Javier Prieto, ${ }^{40}$ may seem unattainable or even inappropriate in our context. However, in practice it is not expected that everyone will reach the maximum of her possibilities. The ideal of a "mature animator" is primarily meant as an appeal to each pedagogue to consider whether she could perhaps develop further in this direction. The point is that leisure time educators offer possibilities and teach young people to handle their lives. It is an imperative of our time that leisure time educators "help children and young people to form life visions", as formulated by the participants of the 10th conference on education and leisure time held in Prague in June 2014. ${ }^{41}$

It needs to be mentioned that there are certain presuppositions which must be met if the animational approach is to be applied successfully. Animation as described here derives from JudeoChristian traditions. While an animator is taken to represent traditional values, she can only offer what she herself knows and acknowledges. If the animator comes from a different, non-Christian cultural environment, she may in some cases prefer other values than the ones described above.

An animator ought to have reached inner maturity so that she can offer her view to others and also so that the differences in opinions of the people around her do not disrupt her integrity. However, it is beneficial when the animator can also search - thereby she gives a personal example to all those she strives to influence. "Fumbling around in life" together motivates the group, while an individual - if left to herself - could fall into despair.

An animator must be well acquainted with the instruments of searching. She ought to be a guide who teaches the group to work with a compass and then sends it out to examine the terrain alone. An animator is not meant to be a "leader" who always knows where to go. She rather ought to help young people find their life path themselves.

\section{Cultural Animation - Philosophical Grounding and Practical Use}

Abstract The team of authors from the Department of Pedagogy at the Faculty of Theology, University of South Bohemia in České Budějovice, follow up on their article The Pluriform Phenomenon of Animation from 2011 and M. Kaplánek's monograph Animation from 2013. While in their publications so far the authors strove rather to specify the concept of "animation" and present the individual lines of animation, this study deals primarily with so-called cultural animation which has become an educational method, and with its use in pedagogical practice. An example of using animation is the programme for animator formation employed by Salesians in Slovakia. This programme is realized within the Catholic Church, which is why this text emphasizes the theological foundations of animation.

Keywords animation; cultural animation; education; leisure time education; Salesians of Don Bosco; Mario Pollo; Riccardo Tonelli

40 Cf. Javier PRIETO, Smer - človek, pp. 208-211.

41 The quotation comes from the conclusions of the conference, available at the document server of Asociace vzdělavatelů pedagogů volného času (online), at: https://drive.google.com/file/d/0B8CRctGvnT2YR0ZmOVA0RTIBT28/view?usp=sharing 